University of Michigan Law School

University of Michigan Law School Scholarship Repository

\title{
Tort as a Substitute for Revenge
}

\section{Scott Hershovitz}

University of Michigan Law School, sahersh@umich.edu

Available at: https://repository.law.umich.edu/book_chapters/122

Follow this and additional works at: https://repository.law.umich.edu/book_chapters

Part of the Legal Remedies Commons, and the Torts Commons

\section{Publication Information \& Recommended Citation}

Hershovitz, Scott. "Tort as a Substitute for Revenge." In Philosophical Foundations of the Law of Torts, edited by J. Oberdiek, 86-102. Oxford: Oxford University Press, 2014.

This Book Chapter is brought to you for free and open access by the Faculty Scholarship at University of Michigan Law School Scholarship Repository. It has been accepted for inclusion in Book Chapters by an authorized administrator of University of Michigan Law School Scholarship Repository. For more information, please contact mlaw.repository@umich.edu. 


\title{
4 \\ Tort as a Substitute for Revenge
}

\author{
Scott Hershovitz ${ }^{*}$
}

\section{Introduction}

In 1872, the Supreme Court of Illinois decided a case called Alcorn v Mitchell. ${ }^{1}$ It was not the first litigation between the parties. Some years earlier, Alcorn had sued Mitchell for trespass. ${ }^{2}$ That suit did not go well, and at the close of the trial, just after the court adjourned, Alcorn spit in Mitchell's face. ${ }^{3}$ Mitchell then turned the tables and sued Alcorn for battery. He won a judgment for $\$ 1,000$, which was a lot of money back then-depending on how you think about the change in value of money over time, the present day equivalent would range from just about $\$ 20,000$ to a bit more than $\$ 250,000 .{ }^{4}$ Alcorn appealed. The question put to the Illinois Supreme Court was whether he had "been made to pay too dearly for [his] indulgence."5

The court did not think so. Toward the end of its opinion, it noted that Alcorn was a "man of wealth." ${ }^{6}$ But it placed more emphasis on what he did than on who he was. "It is customary," the court observed, "to instruct juries that they may give vindictive damages where there are circumstances of malice, willfulness, wantonness, outrage

* Professor of Law and Professor of Philosophy, University of Michigan, Ann Arbor. Thanks to Andrew Gold, John Goldberg, Don Herzog, Bill Miller, John Oberdiek, and the participants in the Legal Theory Workshop at the American University Washington College of Law for helpful comments and conversations.

1 Alcorn v Mitchell, 63 Ill. 553 (1872).

2 The only published opinion in the litigation between Alcorn and Mitchell is the 1872 Illinois Supreme Court opinion from the second suit. It refers to the parties as plaintiff and defendant, without saying who was who. However, the docket in that case (available in the Illinois State Archives) makes clear that Alcorn was the plaintiff in the first suit and Mitchell the plaintiff in the second. See Pleas and Proceedings in the Circuit Court, Alcorn $v$ Mitchell, 65 Ill. 553 (1872) (Supreme Court Docket No. 88, Agenda No. 15) (herinafter "Pleas and Proceedings").

3 The opinion in the later case describes Alcorn as an "exasperated suitor." Alcorn, 63 Ill., at 554.

4 Simply updating for inflation suggests that the equivalent award today would be about $\$ 19,400$. But we might get a better read on the magnitude of the award by gauging its relationship to per-capita gross domestic product (GDP), which was $\$ 195.64$ in 1872 . Since per-capita GDP in 2012 was $\$ 49,927.74$, a similarly sized award today would be roughly $\$ 255,000$. I obtained both measures from calculators at <http://www. measuringworth.com> accessed October 23, 2013.

5 Alcorn, 63 Ill., at 554. Alcorn also challenged the jury instructions, but the court did not address them.

${ }^{6}$ Alcorn, 63 Ill., at 554. 
and indignity attending the wrong complained of. The act in question was wholly made up of such qualities. It was one of pure malignity, done for the mere purpose of insult and indignity."7 Alcorn, the court said, gratified "his malignant feelings in [a] despicable mode." And worse than that, he did so in "the temple of justice... in the very presence of its ministers."

So it seems fair to say that the court did not think much of Alcorn's spit. But why damages, and why such a substantial sum? There is no hint that Mitchell suffered an injury beyond the indignity, no hint that he suffered an injury that money might repair. Yet, the court still saw a purpose to the payment: "The act in question was one of the greatest indignity, highly provocative of retaliation by force, and the law, as far as it may, should afford substantial protection against such outrages, in the way of liberal damages, that the public tranquility may be preserved by saving the necessity of resort to personal violence as the only means of redress." ${ }^{\prime 10}$ In other words, Alcorn had to pay so that Mitchell would not have to strike back. The tort suit was to substitute for the revenge the court worried Mitchell might take absent a civil means of redress.

The idea that tort suits are a substitute for revenge is still with us today. ${ }^{11}$ But it is not clear how the substitution is supposed to work. One possibility is that tort suits are a substitute for revenge simply because some people who would seek revenge are willing to forego it if they can obtain money damages in a tort suit instead. On this picture, tort damages are a payoff to prevent private violence. This is a rather thin sense of substitution, as it does not presuppose any connection between tort and revenge beyond the preferences of potential plaintiffs. In this sense, a scheme of taxpayer-funded trips to Tahiti might substitute for revenge, if victims would forego violence in favor of it.

There is a hint of the payoff picture in Alcorn, when the court says that liberal damages are warranted so that the "the public tranquility may be preserved." 12 But I suspect that the court meant to say more by way of justifying the award. After all, the payoff picture is consistent with a dim view of Mitchell and his pursuit of damages. A better man, the court might have thought, would let the slight slide and not hold the court hostage to the threat of retaliation. But there is no hint in the opinion that the court regrets the need to purchase public tranquility at the cost of liberal damages. Quite the opposite. The court seems pleased to approve the judgment, explaining that " $[\mathrm{s}] \mathrm{o}$ long as damages are allowable in any civil case by way of punishment or for the sake of example, the present, of all cases, would seem to be a most fit one for the award."13

The talk of punishment here suggests another way we might think of the substitution. Today, we would call the damages that Alcorn was ordered to pay "punitive." But though the court clearly saw the damages as a form of punishment, it labeled them

\footnotetext{
7 Alcorn, 63 Ill., at $554 . \quad{ }^{8}$ Alcorn, 63 Ill., at 554.

9 Alcorn, 63 Ill., at $554 . \quad{ }^{10}$ Alcorn, 63 Ill., at 554.

11 See Mathias v Accord Economy Lodging, Inc., 347 F.3d 672, 677 (7th Cir. Ill. 2003) (Posner, J.) (“[A]n an age-old purpose of the law of torts is to provide a substitute for violent retaliation against wrongful injury.").

12 Alcorn, 63 Ill., at $554 . \quad{ }^{13}$ Alcorn, 63 Ill., at 553.
} 
"vindictive," not "punitive." Formally, there is no difference. In most jurisdictions, "punitive" and "vindictive" are used interchangeably to denote extra-compensatory damages awarded for willful or wanton misconduct. But "vindictive" is a revealing label, as it suggests that an award of such damages is responsive to the attitude associated with revenge. And it is a short step from thinking of the damages as vindictive to regarding them as a kind of revenge inflicted through a tort suit. On this picture, the substitution is not so much tort for revenge, as it is a bloodless revenge for a bloody one.

This thought can be developed in different ways. One version carves off punitive damages from the rest of tort, holding that revenge comes into play only when plaintiffs are permitted to seek extra-compensatory damages. ${ }^{14}$ Another takes the label "vindictive" to make manifest as to punitive damages what is true of all tort damages. After all, punitive damages are not the only damages that are painful to pay. This has led some to suggest that a tort suit provides a plaintiff an opportunity to take revenge by inflicting harm on the person who harmed her, even when only compensatory damages are on offer. And that suggestion is sometimes buttressed by the observation that compensatory damages are not nearly so tied to the extent of the plaintiff's injury as the name might suggest. By operation of several different doctrines, they often run beyond or fall short of the plaintiff's losses, making it hard, some say, to take seriously tort's talk about making plaintiffs whole. ${ }^{15}$

I do not doubt that tort can serve as an outlet for vindictive motives, and I think that true even when punitive damages are not in play. But it is a mistake to regard tort damages as a kind of revenge. Tort works rather differently, and not just because it is civil rather than violent. We will see some of the differences later on. For now, I want to continue to catalog ways in which tort might substitute for revenge. We started with the thought that tort might be a way of paying off plaintiffs, so that they refrain from revenge. Then, we considered the possibility that a tort suit (especially, but perhaps not only, a successful one) just is a kind of revenge. The last possibility I want to put on the table is that tort suits are a substitute for revenge because they can be used for the same purposes.

This is obviously true, in at least one respect. Both tort and revenge can be used to deter. You would think twice if the person you spit on might spit back. And you would also think twice if you might be forced to pay $\$ 20,000$ for the privilege. ${ }^{16}$ When the Alcorn court said that it was appropriate to award damages "for the sake of example," deterrence is surely what it had in mind. Of course, there is nothing distinctive about this relationship between tort and revenge. Regulation is a tool for deterrence, and criminal prohibition is too. As means of deterrence, each has its costs and benefits. But though a pairwise comparison between tort and revenge might make tort seem

\footnotetext{
14 See Anthony J. Sebok, "Punitive Damages: From Myth to Theory," 92 Iowa. L. Rev. 957 (2007).

15 See Emily Sherwin, "Compensation and Revenge," 40 San Diego L. Rev. 1387 (2003).

16 The standard idiom here is a bit misleading: damages do not purchase a privilege, not even in retrospect, as paying damages does not legitimize the conduct that led to them.
} 
attractive, it is far less certain that tort holds up well against the others, at least for much of the conduct that can underwrite a tort suit. It seems doubtful, for example, that the best way to deter medical malpractice, or risky driving for that matter, is through a system of private tort suits. So if we have deterrence in mind, we might end up thinking that tort is a substitute for revenge, but far from the best available.

Deterrence, however, may not be the only purpose to which both tort and revenge could be put. Another possibility is that they can both be used to do corrective justice. This will not seem an odd thought as to tort, as philosophers have long argued that tort suits enforce moral duties of repair. ${ }^{17}$ But it will strike many as an odd thought as to revenge, which we are often told has little to do with justice. ${ }^{18}$ Of course, that is a distinctly modern attitude. Francis Bacon pronounced revenge "a kind of wild justice," ${ }^{\prime 19}$ even as he warned against it. And for those who followed the law of the talion, getting justice meant getting even, often through violent retaliation.

I think that Bacon and adherents of the talion had it right: revenge is a tool for doing corrective justice. And tort is a substitute for revenge because it is too. Of course, the thought that tort is a tool for doing corrective justice is not novel. But it is often misunderstood, and reflecting on revenge can help us see why. My aim in this chapter is to think through what Mitchell might have gotten from revenge and what tort offered him in its place. But before we do that, it will help to think a bit about corrective justice.

\section{Corrective Justice}

Contemporary thinking about corrective justice is dominated by a picture that we owe to Aristotle. Aristotle imagined two parties in an initial position of equality, represented by a line divided into equal segments. When one party disturbs that equality, lengthening her own segment and shortening the other's, corrective justice demands that we restore the equality, taking from the party with the lengthened segment just what is necessary to restore the shortened one. ${ }^{20}$

On this way of thinking, corrective justice is all about allocation. Here is how John Gardner explains it:

\footnotetext{
17 The classic statements of the corrective justice take on tort law are: Jules Coleman, Risks and Wrongs (Cambridge: Cambridge University Press, 1992), and Ernest J. Weinrib, The Idea of Private Law (Cambridge, MA: Harvard University Press, 1995).

18 See Gabriel Seltzer Mendlow, "Is Tort Law a Form of Institutionalized Revenge," 39 Fla. St. U. L. Rev. 129 (2011) ("Most would agree that institutions of revenge have no place in a just society..."); See also Robert Nozick, Philosophical Explanations (Cambridge, MA: Belknap Press, 1981), 366-8 (distinguishing revenge from retribution and suggesting that the latter has a connection to justice that the former does not).

19 Francis Bacon, "Of Revenge," in Brian Vickers (ed.), Francis Bacon: The Major Works (Oxford: Oxford University Press, 2002), 347.

${ }^{20}$ Aristotle, Nicomachean Ethics, bk. V, Roger Crisp (ed. \& trans.) (Cambridge: Cambridge University Press, 2000), 88.
} 
Something has shifted between ... two parties. The question of corrective justice is not the question of whether and to what extent and in what form and on what ground it should now be allocated among them full stop, but the question of whether and to what extent and in what form and on what ground it should now be allocated back from one party to the other, reversing a transaction that took place between them. ${ }^{21}$

The Aristotelian picture fits some forms of wrongdoing well. If Alcorn had stolen Mitchell's horse, corrective justice might demand that he give it back, reversing the wrongful transaction.

But Alcorn did not steal from Mitchell. He spit on him. To be sure, something shifted between them. But it hardly seems that the question of corrective justice in this case could be about the allocation of Alcorn's spit. After all, the problem here is not that Mitchell possesses something to which he has no right; it is that he was subjected to treatment that he had a right to be free from. And there is no way to reverse that transaction. This is not because we cannot force the spit back on Alcorn. Perhaps we could. But even if we did, that would not change the fact that Mitchell was spit upon.

Of course, we could say much the same when Alcorn steals Mitchell's horse. Mitchell had a right to his horse, which Alcorn infringed when he stole it. Corrective justice might well demand that Alcorn return the horse, but there is no changing the fact that Mitchell stole it. And we might wonder whether corrective justice requires that we do anything about that. After all, returning the horse is just what we would expect Alcorn to do had he found it, so it hardly seems an adequate response to the fact that he stole it.

Now one possibility is that corrective justice demands only that Alcorn return the horse, leaving other moral principles to determine whether a further response to his wrongdoing is warranted. This is Gardner's view. He says that norms of justice are "norms for tackling allocative moral questions, questions about who is to get how much of what." 22 Within that domain, norms of corrective justice address questions about allocating something back from one person to another, once it has shifted as the result of wrongdoing. ${ }^{23}$ But that is all corrective justice does. If there is more to be done in response to wrongdoing, it is not because corrective justice calls for it. ${ }^{24}$

I find this conception of corrective justice much too cramped. It has the consequence that many of the most serious wrongs do not call for corrective justice at all, as they do not involve transfers that can be reversed through reallocation. If Alcorn had raped Mitchell, for example, there would be no corrective justice to be done, as there would be no horse to hand over. So too with the spit. And that is a rather startling conclusion.

Part of the problem here stems from the fact that wrongdoing does not always generate a gain for the wrongdoer that matches the victim's loss. Had Alcorn stolen Mitchell's horse, he would have gained the very thing that Mitchell lost. But Alcorn

\footnotetext{
21 John Gardner, "What is Tort Law For? Part I. The Place of Corrective Justice," 30 Law \& Philosophy 1 (2011), 9-10 (hereinafter "What is Tort Law For? Part I").

22 Gardner, "What is Tort Law For? Part I" (note 21) at 6.

${ }^{23}$ Gardner, "What is Tort Law For? Part I" (note 21) at 9-10.

${ }^{24}$ Gardner, "What is Tort Law For? Part I" (note 21) at 47.
} 
may not have gained anything from spitting on Mitchell, and if he did gain something (satisfaction, perhaps), it is neither the thing that Mitchell lost, nor something that he could hand over. So the Aristotelian imagery is off: Mitchell's segment of the line may have been shortened, but Alcorn's does not seem to have been lengthened. And even if it was, we cannot rejigger the lines to get back where we started.

This sort of worry leads some to tweak the Aristotelian picture, so that corrective justice requires restoring Mitchell's segment of the line, even if that will leave Alcorn with a shorter segment than he started with. The idea here is that the loss that Alcorn inflicted on Mitchell is properly his to deal with, so he must restore Mitchell to his rightful position and handle the consequences on his own. ${ }^{25}$ And there are cases in which it looks like this might work. If Alcorn destroyed Mitchell's horse, for example, then requiring that he pay Mitchell its market value would seem to make the loss Alcorn's to deal with. Mitchell would be able to acquire more or less what he lost and, Alcorn would be out money, not Mitchell.

But the problem here should be apparent, as it is symmetrical to the one we just faced. Many kinds of wrongdoing do not involve losses that can be shifted to the wrongdoer. It is not obvious, for example, that Mitchell lost anything when Alcorn spit on him, but if he did (some measure of dignity, perhaps), it is not the sort of loss he can transfer to Alcorn. This would be even more stark had Alcorn physically injured Mitchell. If he had put his eye out, for example, we could transfer some of the consequential losses (medical expenses, lost income, and the like) and make them Alcorn's problem, rather than Mitchell's. But Mitchell would surely miss his sight, and he could not pass that loss on to Alcorn.

Of course, there is a touch of this problem in the horse case too. As I said, Mitchell might use his damages to acquire more or less what he lost. But he cannot recover just what he lost-that horse has left the barn-and the difference might well matter. So it turns out that, even when we tweak the Aristotelian imagery, it can serve as a picture of corrective justice only for a narrow set of cases: those in which the victim has lost a commodity, and just that. In all other cases, the victim must suffer at least some of her loss herself.

The Aristotelian picture holds out a false promise. ${ }^{26}$ It makes it seem like we can get back where we started; we just have to rejigger the line. But we can never get back where we started. When one person wrongs another, the wrong is part of our history, indelibly, and the challenge is to figure out how to go on, not how to go back. Of course, everyone who writes about corrective justice appreciates this, at least to some

\footnotetext{
25 See, e.g., Arthur Ripstein, Equality, Responsibility, and the Law (Cambridge: Cambridge University Press, 2001), 58 ("But insofar as they enable a plaintiff to adapt to his or her situation, money damages are an appropriate way of transferring the loss so that it becomes the injurer's problem to decide how to deal with what is properly his or her loss.").

${ }^{26}$ I develop this argument further in Scott Hershovitz, "Corrective Justice for Civil Recourse Theorists," 39 Fla. St. L. Rev. 107 (2011), 100-17. John Goldberg and Ben Zipursky sound similar themes when they argue that loss-focused conceptions of corrective justice do not make sense of tort doctrine. See John C.P. Goldberg and Benjamin C. Zipursky, “Torts and Wrongs," 88 Texas L. Rev. 917 (2010), 954-7.
} 
degree. So they douse their claims in qualifiers. They say that corrective justice consists in "undoing, to the extent possible, the very injustice that has been committed," "restoring things, at least in some measure, to where they would have been had one not occasioned their loss." ${ }^{28}$ And maybe we should do these things when we can. But these qualifiers are a dodge. We can never restore things to just the way they were, and all too often, we cannot restore them at all. So if that is what corrective justice demands, we are bound to fall short in all cases, and we will not be able to do anything that counts as corrective justice in many.

That would be depressing, if it were true. It would be nice to think that we could do corrective justice for Mitchell, whether Alcorn steals his horse, spits on him, or sexually assaults him. And it would be nice to think that our ability to do so does not depend on the happenstance of Mitchell having incurred losses that we could shift to Alcorn through a damage award. Happily, I think that we can offer Mitchell corrective justice in all these cases. But to see how, we need to set the Aristotelian picture aside and make a fresh start.

\section{Corrective Justice Corrected}

Let us turn our attention back to the actual facts of Alcorn v Mitchell. Alcorn had sued Mitchell for trespass. The charge seems to have been that Mitchell took down Alcorn's fence without permission. ${ }^{29}$ Mitchell testified on his own behalf, apparently in a manner that Alcorn found damaging. When the court adjourned, Alcorn approached Mitchell and spit in his face.

But it was not just any spit, at least not according to Mitchell. Here is how his complaint described the event:

[T] he plaintiff... avers that because he the plaintiff did and would testify the truth the whole truth and nothing but the truth and because the same proved to be matter against... Alcorn in his said suit... Alcorn then and there did willfully, maliciously and Devilishly spit upon the plaintiff, and then and there for the cause and reason aforesaid squirted into the face and eyes of the plaintiff a large quantity of filthy matter out of and from the mouth of the defendant, consisting of saliva, mingled with divers filthy noisome and disgusting drugs, whiskey and other kinds of nastiness then and there prepared by the defendant for the express purpose of being by him squirted in the plaintiff's face as aforesaid. ${ }^{30}$

The court's worry that Mitchell might strike back was not fanciful. His complaint continued:

27 Ernest J. Weinrib, Corrective Justice (Oxford: Oxford University Press, 2012), 36 (emphasis added).

28 Gardner, "What is Tort Law For? Part I" (note 21) at 37 (emphasis added).

29 Testimony of J.B. Gillaspie, Records from Marion County Proceedings, 3, Alcorn v Mitchell, 65 Ill. 553

(1872) (Supreme Court Docket No. 88, Agenda No. 15) (hereinafter "Testimony of J.B. Gillaspie”).

${ }^{30}$ Pleas and Proceedings, at 4-5. 
[T] he people who were present demand[ed] that the plaintiff ought to have then and there killed the defendant, which temptation the plaintiff resisted out of respect to the laws of God and the State, and to the great displeasure and disgust of the numerous. To wit, One hundred bystanders who were indignant that so gross an insult should pass unrevenged. ${ }^{31}$

It is hard to know how seriously to take all that, but the court took it seriously enough to uphold significant damages, on the ground that the act in question was highly provocative of retaliation by force.

But our question is not whether Mitchell would have actually taken revenge had he not been able to file a tort suit. It is what he would have gotten from revenge had he taken it. For guidance, we can look again to the complaint, which recounts the fallout from having let the insult pass: "[I]n consequence the plaintiff hath been greatly injured in his feelings in his circumstances, his credit and his reputation." 32 That sounds a bit like boilerplate, but, on these facts, it is easy to believe, and it is worth asking why.

The answer, I think, is that Alcorn's spit sent a message. Here is how Jeffrie Murphy explains the messages implicit in moral injury:

One reason we so deeply resent moral injuries done to us is not simply that they hurt us in some tangible or sensible way; it is because such injuries are also messages-symbolic communications. They are ways a wrongdoer has of saying to us, "I count but you do not," "I can use you for my purposes," or "I am here up high and you are there down below."

That last message, especially, would have been easy for Alcorn's audience to take away. As the court's opinion noted, Alcorn was a wealthy man; estimates of his net worth at trial ranged from $\$ 50,000$ to $\$ 200,000$ (or somewhere between $\$ 1$ and $\$ 4$ million, updated for inflation). ${ }^{34}$ Mitchell, on the other hand, was said to be worth just $\$ 2,000 .^{35}$ So people may well have been primed to hear the message that Alcorn was up high and Mitchell down low. Indeed, it is easy to imagine that the very point of Alcorn's spit was to reassert that message in the wake of the court crediting Mitchell's testimony rather than his own.

Messages of this sort matter. As Murphy says: "Most of us tend to care what others (at least some others, some significant group whose good opinion we value) think about us-how much they think we matter. Our self-respect is social in at least this sense, and it is simply part of the human condition that we are weak and vulnerable in these ways." 36

\footnotetext{
31 Pleas and Proceedings, at $5 . \quad 32$ Pleas and Proceedings, 5.

${ }^{33}$ Jeffrie G. Murphy, "Forgiveness and resentment," in Jeffrie G. Murphy and Jean Hampton, Forgiveness and Mercy (Cambridge: Cambridge University Press, 1990), 25.

34 The estimates of Alcorn's net worth appear in transcripts of testimony contained in Records from Marion County Proceedings, 2, Alcorn v Mitchell, 65 Ill. 553 (1872) (Supreme Court Docket No. 88, Agenda No. 15). Once again, I have taken rough inflation figures from $<$ http://www.measuringworth.com $>$. If you prefer to compare the figures to per-capita GDP, then present equivalent of Alcorn's net worth would range from $\$ 12$ million to $\$ 50$ million.

35 Argument and Brief of Appellee, Alcorn v Mitchell, 65 Ill. 553 (1872) (Supreme Court Docket No. 88, Agenda No. 15).

36 Murphy, "Forgiveness and resentment" (note 33) at 25.
} 
That vulnerability makes messages of the sort Alcorn's spit sent threatening, and the threat lingers if we do not respond to them. Here's how Pamela Hieronymi puts it:

I suggest that a past wrong against you, standing in your history without apology, atonement, retribution, punishment, restitution, condemnation, or anything else that might recognize it as a wrong, makes a claim. It says, in effect, that you can be treated this way, and that such treatment is acceptable. ${ }^{37}$

To be clear, the threat that Hieronymi means to highlight is not that you might be subjected to the same treatment again, though that may be a worry if people come to think it is acceptable to treat you that way. Rather, the threat is to your social standing, which is diminished if people think it was okay to treat you that way, even if it is not likely to happen again. ${ }^{38}$

The simplest way to recognize a wrong is to resent it, and many philosophers have thought resentment vital to self-respect. Heironymi argues that resentment is warranted when you hold three judgments:

(1) The act in question was wrong; it was a serious offense, worthy of moral attention. (2) The wrongdoer is a legitimate member of the moral community who can be expected not to do such things. As such, she is someone who can be held responsible and she is worth being upset by. (3) You, as the wronged, ought not be wronged. This sort of treatment stands as an offense to your person. ${ }^{39}$

If Mitchell had been able to deny any of these propositions, he would have had no need for resentment. If, for example, he thought that Alcorn was not worth being upset by, he could simply dismiss him. But Mitchell probably thought that Alcorn mattered, and given the crowd's reaction, he surely knew that other people did. In those circumstances, if Mitchell could not even muster so much as resentment in protest of Alcorn's spit, then he would seem to concede that he may be spit upon, at least by the likes of Alcorn.

But though resentment would have been a way for Mitchell to resist the thought that he may be spit upon, it would not have been, by itself, a terribly effective way of countering the threat to his social standing. Hence, Hieronymi's list: apology, atonement, retribution, punishment, restitution, and condemnation. To different degrees, these are all public performances that would mark Alcorn's behavior as wrong, and thus stand as a counterweight to the message that his spit sent. Revenge does not make Hieronymi's list, but she later adds that 'taking revenge might be one way to 'correct' the historical significance of the event, marking it as a wrong." 40

I think that is right, and I do not see any reason for the scare quotes. Had Mitchell done as the crowd demanded and killed Alcorn, he would have sent the message that

\footnotetext{
37 Pamela Hieronymi, “Articulating an Uncompromising Forgiveness," 62(3) Philosophy and Phenomenological Research 529 (2001), 546.

38 Hieronymi, “Articulating an Uncompromising Forgiveness" (note 37) at 548, n. 31.

39 Hieronymi, "Articulating an Uncompromising Forgiveness" (note 37) at 530.

40 Hieronymi, "Articulating an Uncompromising Forgiveness" (note 37) at 548.
} 
he may not be spit upon, that he regards it is an offense to his person, which he takes seriously and will not tolerate. Of course, killing Alcorn seems much too much, as it suggests that the wrong was much graver than it in fact was. There were surely responses short of death that would have countered the message in Alcorn's spit. Indeed, there's a certain genius in the law of the talion, with its famous formula an eye for an eye. When a victim treats a wrongdoer just the way the wrongdoer treated her, she communicates that she was wronged and will not stand for it. But she also claims a kind of equality - an entitlement to treat others as they treat her.

That equality is central to the way that revenge works, or at least it was for adherents of the talion. For them, getting justice was about getting even. But the evenness involved was not about allocation, as the Aristotelian conception of corrective justice would have it. Rather, it was an evenness in a certain kind of social standing, expressed in a formula that inverts the golden rule: you may do unto others as they do unto you. Much modern commentary about revenge misses this. The mistake is on display in Robert Nozick's suggestion that "[r] etribution sets an internal limit to the amount of punishment, according to the seriousness of the wrong, whereas revenge internally need set no limit to what is inflicted." 41 There's a logic to the talion, and the logic is largely about limits; getting even is not going postal. ${ }^{42}$

To be sure, most revenge cultures left some play in the joints. The rules were not so rigid as to require that the victim do to the wrongdoer just what the wrongdoer did to her. But it better be possible to sell the response as a way of getting even, or it would not be seen as a justified act of revenge. ${ }^{43}$ And that leads me to doubt that Mitchell would have killed Alcorn over the spit, or that he would have been treated well had he done so. It also leaves me a little suspicious of his claim that the crowd demanded it. But it might have: Alcorn's spit presumably posed a threat to many in the crowd (if it was okay for Alcorn to spit on Mitchell, it might be okay for him to spit on them too), and in the heat of the moment crowds often take things too far.

Whatever the crowd demanded, we are now in a position to appreciate at least one thing that Mitchell would have gotten from taking revenge. He would have countered Alcorn's message about his social standing. And if his revenge was properly calibrated, he would have asserted, in at least one fundamental sense, that he was Alcorn's equal. That strikes me as a kind of justice, and indeed corrective justice. But what corrective justice so construed corrects is the historical significance of the wrong-the threat that it poses-and not an aberration in the prevailing allocation of goods.

${ }^{41}$ Nozick, Philosophical Explanations (note 18) at 367.

${ }^{42}$ William Ian Miller, Eye for an Eye (New York: Cambridge University Press, 2006), 24 (“[W]e think of revenge as going postal and blasting away, but revenge cultures did not think of it that way. For them, revenge was not just an ethic but an aesthetic, the aesthetic of proportion and balance.").

${ }^{43}$ I explore getting even in more detail in Hershovitz, "Corrective Justice for Civil Recourse Theorists" (note 26) at 117-25. As I emphasize there, getting even has a performative dimension, and success in the performance depends in part on prevailing assessments of value. 


\section{The Message in the Money}

What did Mitchell get from his tort suit? Money, of course. But the suggestion I want to make is that the money was paid in service of a message that is much the same as the message Mitchell would have sent by taking revenge. In finding Alcorn liable for battery, the jury marked his conduct as wrong, rebutting any suggestion that it was permissible for him to spit on Mitchell. And this was not just a pro forma prelude to the damage award. Quite the contrary. The message seems to have been just what Mitchell was after when he filed suit. In settlement negotiations, Mitchell told Alcorn that "all he wanted" was for "Alcorn to acknowledge that he'd done wrong." ${ }^{4}$ Indeed, he disclaimed any interest in Alcorn's money, explaining that he filed suit only after his attorney, among others, told him that he "ought not to stand it to be spit on." 45 So it seems apt to say that the lawsuit was Mitchell's way of standing up for himself.

Of course, the jury did not just find Alcorn liable; it imposed \$2,000 in vindictive damages (the trial court reduced the award to $\$ 1,000$ for reasons that are not clear from the record). Why damages, and why such a substantial sum? For the same reason that Alcorn spit on Mitchell. He could have hurled insults at him, but his spit showed a contempt that words could hardly communicate. (As the old saying goes, actions speak louder than words.) The jury was in much the same position. It could have simply said that Alcorn had wronged Mitchell, entering a nominal damage award, if that was formally required. By attaching substantial damages to its verdict, the jury made its message unmistakable: Alcorn's conduct was wrong, and seriously so. That message still comes through loud and clear today. My students are routinely shocked at how seriously the jury took Alcorn's spit, as none of them can imagine being ordered to pay $\$ 20,000$, let alone $\$ 250,000$, for a similar transgression today.

This is not the story that corrective justice theorists commonly tell about punitive damages. They tend to argue that punitive damages are surreptitiously compensatory, so that they fit into the Aristotelian picture, or that they are out of place, since a plaintiff does not have a claim to the money (or anything equivalent) prior to the wrong. ${ }^{46}$ But punitive damages can clearly contribute to corrective justice if one takes on board the suggestion that corrective justice is about correcting the message that

\footnotetext{
44 Testimony of J.B. Gillaspie, 3. Alcorn did eventually apologize. According to Gillaspie, he acknowledged that "it was a little thing to spit on any man." He also said it was "no credit to him" that he had done so, that it was "wrong" and that he was "sorry." Nevertheless, the case did not settle. Some witnesses suggested that attorneys' fees held up the settlement; Alcorn offered to pay \$25 toward attorneys' fees, but Mitchell’s attorneys likely stood to do much better than that with a contingency fee. However, there are reasons to doubt that the attorney stood in the way. One witness reported that Mitchell's lawyer told him that he "could do as he pleased about settling," but that "he would not let any man spit in his face for ten thousand dollars." Testimony of A.J. Douherty, Records from Marion County Proceedings, 3, Alcorn v Mitchell, 65 Ill. 553 (1872) (Supreme Court Docket No. 88, Agenda No. 15). I think it is possible that Mitchell used his attorney as a convenient excuse. Apologies are easy to fake, and by the time Mitchell filed suit, he may well have come to prefer public vindication to an apology offered only as an inducement to settle.

45 Testimony of J.B. Gillaspie. 3.

46 See Benjamin C. Zipursky, “A Theory of Punitive Damages," 84 Texas L. Rev. 105 (2005), 136.
} 
wrongdoing sends, not about altering allocations in an effort to restore the status quo ante. Punitive damages help mark the gravity of a wrong. And because juries are permitted to consider the defendant's wealth when imposing them, they can ensure that the victim's dignity will not be seen as something available for purchase (at least not without a price that is painful).

But what should we think, then, about compensatory damages, which often do seem like an effort to restore the status quo ante, or at least aspects of it? They serve a communicative purpose too. Once again, here is Hieronymi:

[A]ny wrongdoing leaves in its wake some amount of damage or cost, be it physical, financial, emotional, relational, or social. This is damage which the offender usually cannot repair ("you can't take it back," as children learn), and which the offended will, in any case, incur. The persistence of the damage threatens any attempt to leave the past in the past, insofar as the damage testifies to the deed. ${ }^{47}$

Hieronymi is refreshingly upfront about the problem that corrective justice theorists tend to gloss over: a victim almost always suffers damage that cannot be repaired. Hieronymi argues that when a victim forgives a wrongdoer she agrees to bear that damage without further protest. ${ }^{48}$ And that strikes me as right. But her observation can also help us explain why we might require a wrongdoer to undo the damage, or mitigate its costs when he can. So long as the damage persists, it "testifies to the deed," and leaves the threat to the victim's social standing in place: it just might be okay to treat her that way, because she was treated that way, and she has been left to absorb the consequences, even though they might have been repaired. When we require repair, we affirm the message that the conduct in question was wrong and the results the wrongdoer's responsibility.

The same observation can also help explain why we invite juries to award compensation for injuries that cannot be repaired, or even sensibly valued in monetary terms. Pain and suffering damages, for example, do not fix pain and suffering. And there is typically no price at which people would agree to endure serious pain and suffering, so the damages cannot be set to simulate a market rate. But pain and suffering damages still serve a purpose: they mark the pain and suffering as the responsibility of the defendant. To do that effectively, their magnitude must reflect the weight of the injury that the plaintiff must bear. Thus, serious suffering merits a serious sum, even though the serious sum cannot be taken seriously as a price or means of repair.

The bottom line is that tort law does not do corrective justice only, or even primarily, by enforcing moral duties of repair. It does, to be sure, enforce duties of repair. But not all tort damages are reparative, and they are no less a part of corrective justice for that. Moreover, the damages that are reparative do corrective justice in the same way that the non-reparative damages do. They do justice through the message that they send about the victim's standing and the wrongdoer's responsibility. ${ }^{49}$

\footnotetext{
47 Hieronymi, “Articulating an Uncompromising Forgiveness” (note 37) at 550.

48 Hieronymi, “Articulating an Uncompromising Forgiveness" (note 37) at 551.

49 Stephen Smith gestures toward a similar view of the relationship between tort damages and corrective justice near the end of his "Why Courts Make Orders (And What This Tells Us About Damages)," 64 Current Legal Problems 51, 84-86 (2011). However, he stops short of embracing a communicative picture of either
} 


\section{Tort or Revenge?}

The lesson so far is that, in at least one important respect, tort offered Mitchell the same thing that revenge did. It offered him a way of countering the message that Alcorn's spit sent, a way of correcting the historical significance of Alcorn's wrong. Tort law did not just pay off Mitchell to purchase public tranquility; it saved him the necessity of resort to private violence by offering him a civil means to do what he might have done through force. This is the chief reason tort and revenge are substitutes: they can both be used to do corrective justice.

Which is the better way to do it? Tort has one obvious advantage. It is civil rather than violent, and to the extent we can, it seems better to correct the historical significance of wrongs without inflicting further injuries. This is true for many reasons. Justice is just one virtue among others. We should also aim to treat people humanely. Sometimes that might require that we accept less justice, or forego it altogether. But it might just require that we do justice differently, accepting civil means of redress when they provide a suitable substitute for revenge.

Tort has another important advantage too: when a tort suit is successful, representatives of the community hold the wrongdoer responsible. That public vindication may abate the threat that wrongdoing poses to its victim more effectively than any action the victim might take on her own. As Murphy says, "our self-respect is social,"50 and because of that, victims have special reason to prize the communal affirmation reflected in a tort judgment.

But we should be careful not to overestimate the difference between tort and revenge on this point. Revenge is rarely just a private performance. Recall that the crowd demanded that Mitchell take revenge. That provided some communal affirmation even before he filed his tort suit. And that sort of thing was not uncommon. Representatives of the community often played a role in revenge, sometimes by taking sides in the dispute, and sometimes by judging what it would take to get victim and wrongdoer even. Indeed, I have argued elsewhere that we can view tort as the institutionalization of the oddman, a character who was often available in revenge cultures to weigh in on what would get the parties even when they could not reach an agreement on their own. ${ }^{51}$ So when it comes to public vindication, the difference may be in degree, not kind.

But elsewhere, revenge has clear advantages over tort. A victim can take revenge on her own, and if she needs help, she can get it from family or friends. She does not need to invoke complicated legal proceedings or hire a lawyer to help her navigate them.

corrective justice or tort. Smith comes at the problem from a different angle, and I am not sure that I agree with everything he says along the way. But I do think he is gesturing in the right direction, and I hope here to have explained why.

${ }^{50}$ Murphy, "Forgiveness and resentment"(note 33) at 25.

${ }^{51}$ Hershovitz, "Corrective Justice for Civil Recourse Theorists" (note 26) at 124-5. For more on oddmen, see Miller, Eye for an Eye (note 42) at 9-11. 
And there may be special value in vindicating one's worth oneself (you would rather be the kid who can handle things on her own than the one who has to appeal to the teacher for help). But I think the most important advantage revenge has is that it can send a wider array of messages than tort. Tort has limited tools-money damages, and occasionally injunctions. Sometimes, that will be enough. But in cases that involve serious wrongdoing, those remedies will not be able to send a very satisfying message. Ordering a rapist to pay medical expenses, for example, or even punitive damages, does not really get at the gravity of the wrong. Here you can see the beginnings of an argument for the fearsome consequences that criminal law imposes. I will return to those shortly. The point for now is that in the most extreme cases, revenge can deliver more complete corrective justice than tort law can. At the limit, there is always death, and ever more gruesome ways of dispensing it. And that makes the range of messages available almost limitless. ${ }^{52}$

There is more to say, on behalf of both tort and revenge, but I will stop for now. There is no chance that we will replace tort with a regime of revenge, and I do not think that we should. But we should remember that revenge has virtues that tort cannot match.

\section{Corrective Justice and Criminal Law}

Though the relationship between tort and criminal law is too large a topic to take on here, I want to say a few words about how criminal law fits into the picture. A standard way of carving legal institutions assigns tort the aim of corrective justice and criminal law the aim of retributive justice. This is much too neat. As I just suggested, when the tools available to tort law are not up to the task, it is natural to look to the criminal law to correct the historical significance of wrongdoing. Sometimes, this may be because the tort remedies are in themselves unsatisfying. Other times, it may be because the wrongdoer is judgment proof, and hence immune to the main tool tort uses to send its messages. In both cases, criminal punishment might do what tort cannot: affirm the victim's standing by responding to the wrongdoing in a way that conveys its gravity.

Of course, this is not all criminal law does, and when it does this, it does it indirectly. In a tort suit, a plaintiff files a complaint against a person she believes wronged her, and the point of the process is to decide whether that plaintiff was wronged and what should be done about it if she was. The person who would be a plaintiff in a tort suit is typically a bit player in criminal proceedings. If she has a role at all, she is there to offer evidence, not make a claim of her own. Victim impact statements and criminal restitution orders blur this line a bit. But in the main, criminal proceedings are about the defendant, and not the claims that a victim might have on the defendant.

\footnotetext{
52 Almost, but not quite. History has given us more than a few monsters against whom no revenge would be satisfying.
} 
There may be a distinctive sort of justice pursued through criminal law. Certainly, many people think that criminal law deals in retributive justice, which they take to be concerned with the question how a wrongdoer deserves to be treated, quite apart from the question what the wrongdoer might owe his victim. I am not sure that there is a distinct kind of justice here, but if there is, I am quite certain that criminal proceedings can do corrective justice too-and not just when restitution orders are tacked on. Outside the courtroom, we find it natural to think that criminal punishment delivers justice for the victims of a crime. That thought is hard to square with standard notions of retributive justice, which is not normally taken to be personal in that way. ${ }^{53}$ But it is easy to understand on a communicative picture of corrective justice. Punishing a defendant for a wrong that had a victim helps abate the threat to the victim's social standing by affirming that she was mistreated and by marking the gravity of that mistreatment. By the same token, declining to prosecute crimes that have victims risks leaving the threat in place, and perhaps reinforcing it, especially where there are no other public proceedings that mark the conduct as wrong. There are good reasons not to give victims the same control over criminal proceedings that they have over civil proceedings, as there is more at stake in a criminal trial than corrective justice. ${ }^{54}$ But victims are stakeholders in the criminal process because corrective justice is among the things at stake.

\section{Conclusion}

I want to close in a courtroom several hundred miles from the one in which Alcorn spit on Mitchell, with a suit that was filed more than a hundred years later. The plaintiff was an anti-smoking advocate named Ahron Leichtman. He was a guest on Bill Cunningham's radio show, invited to discuss the dangers of secondary smoke. According to Leichtman's complaint, another host at the station, Andy Furman, repeatedly blew cigar smoke in Leichtman's face during the interview. Cunningham egged him on. Leichtman sued Cunningham, Furman, and the radio station for battery. The trial court dismissed the claim, but the Ohio Court of Appeals revived it. ${ }^{55}$

\footnotetext{
53 Nozick, Philosophical Explanations (note 18) at 367 (distinguishing revenge from retribution in part on the ground that revenge is personal, whereas retribution is not).

${ }^{54}$ For a guide to some of those reasons, see John Gardner, "Crime: In Proportion and in Perspective," in Offences and Defences: Selected Essays in the Philosophy of Criminal Law (Oxford: Oxford University Press, 2007), 213-38. I agree with much of what Gardner says, but I think he has too narrow a view of the relationship between criminal law and revenge. He argues that one function of the criminal law is to displace revenge by satisfying the retaliatory desires of victims, so far as consistent with its other aims. I do not disagree with that, but Gardner seems to have something like the payoff picture in mind, as he shows little respect for those retaliatory desires. He describes them as often excusable, but rarely justifiable. To the contrary, I think revenge is often warranted, or at least it would be absent institutions like tort and criminal law that remove the warrant by providing alternative means of doing justice. And providing alternative means of doing justice strikes me as the more important function of the criminal law, at least insofar as revenge is concerned.

55 Leichtman $v$ WLW Jacor Communications, Inc., 92 Ohio App. 3d 232, 634 N.E.2d 697, 698 (Ohio. Ct. of App. 1994).
} 
The court's opinion is short, and the lion's share of the discussion addresses the elements of battery. The court concludes that the particulate matter in smoke can make contact, and that blowing it in someone's face is offensive. Thus, it holds that Leichtman stated a valid battery claim and sends the case back to the trial court for further proceedings. But not without comment. These passages appear near the end of the opinion:

Arguably, trivial cases are responsible for an avalanche of lawsuits in the courts. They delay cases that are important to individuals and corporations and that involve important social issues. The result is justice denied to litigants and their counsel who must wait for their day in court....

This case emphasizes the need for some form of alternative dispute resolution operating totally outside the court system as a means to provide an attentive ear to the parties and a resolution of disputes in a nominal case. Some need a forum in which they can express corrosive contempt for another without dragging their antagonist through the expense inherent in a lawsuit. ${ }^{56}$

The contrast with the attitude of the Alcorn court could hardly be more stark. This too was an act "done for the mere purpose of insult and indignity." 57 But the court does not say that the law should afford liberal damages, or make an example out of Furman. Instead, it calls the case "trivial" and "nominal," and it suggests that Leichtman, not Furman, needs a better outlet for his "corrosive contempt."

There are, of course, reasons to think Furman's wrong less significant than Alcorn's. I would rather have smoke blown in my face than suffer Alcorn's spit, and I suspect I am not alone in that. We also take insults less seriously nowadays. And, of course, the place where this one happened matters too. A radio studio is not a temple of justice. Finally, it is tempting to say that Leichtman knew what he was getting into when he went on the show. These were well-known shock jocks, and Leichtman had mixed it up with them before. ${ }^{58}$ We must tread carefully here, however. We are talking about a battery, and "he was asking for it" is just one letter off from "she was asking for it." But even if you think (mistakenly) that going to a place where you know you might be mistreated mitigates the mistreatment, at best all these differences add up to reason to limit Leichtman's damages, not reason to bar his claim from court.

Unless, that is, you do not think Furman's treatment of Leichtman mattered. And that is the unmistakable message of the court's parting comment. There are important social issues to resolve (some of them presented by corporations!), and the affront to Leichtman's dignity is not one of them. Of course, there is the half-hearted suggestion that Leichtman should have some other forum - totally outside the court systemin which to express his corrosive contempt for Furman and friends. But kicking

\footnotetext{
56 Leichtman, 634 N.E.2d, at $700 . \quad{ }^{57}$ Alcorn, 63 Ill., at 554.

58 The suit arose from Leichtman's second appearance on the radio station. During an earlier interview, Furman smoked a cigar. Afterward, Leichtman filed a complaint with the city health department, which cited the station for violating an ordinance that banned smoking in private workplaces. "Cigar smoke can be used as weapon, Ohio court rules," The Tuscaloosa News (January 30, 1994), 2A.
} 
Leichtman's claim to kiddie court and casting him as the person whose behavior is corrosive already downgrades his dignity. Sure, he was battered, but why bother with that?

The court did not want to do corrective justice for Leichtman. It sent his case back grudgingly, since it thought the Ohio Constitution required it. But in doing so, it undermined the message that a verdict for Leichtman would send. I have some sympathy for the court's attitude. Leichtman was mistreated, but his suit may have been motivated more by a desire to gain publicity than by the slight. ${ }^{59}$ (When the suit settled, Leichtman got an hour of airtime to say as he pleased. ${ }^{60}$ So Leichtman may not have been a compelling candidate for corrective justice. But the court's hostility was not reserved for him; it took his case as representative of an avalanche of trivial suits. And there is a lesson to learn from its screed. Tort is structured to do corrective justice. But its capacity to do corrective justice is not just a function of its structure. Justice is not just about who has what, and courts do not do justice just because they move money around in response to wrongdoing. They do justice, when they do, through the messages that they send about our relations to one another. So if we care about corrective justice, we have to make sure that courts have the tools to send the right messages, and that they care enough to use them.

This is all the more important in a society in which revenge is not a serious option. Mitchell might well have killed Alcorn, or seriously injured him, but Leichtman was not going to hurt Furman. We do not do that anymore, or at least most of us do not. We are too civilized, or too timid. Or a bit of both. And it is not clear that it would work anymore anyway. We are so steeped in anti-revenge discourse that we may not hear the messages that revenge aims to send. But if revenge is not an option, then tort better be, at least for any wrongdoing that we think worth taking seriously. Otherwise, victims will not have revenge or an adequate substitute, and they will be left without corrective justice.

\footnotetext{
59 For what it is worth, Leichtman did claim that he was injured. He said that the morning after the interview, he had a corneal abrasion, which prevented him from wearing his contact lenses. See Junda Woo, "Blowing Smoke Around Others May Be Battery," The Wall Street Journal (April 11, 1994), B1.

${ }^{60}$ George W. Jarecke and Nancy Plante, Seeking Civility: Common Courtesy and the Common Law (Boston: Northeastern University Press, 2003), 20.
} 